\title{
Separation of Radiocopper ${ }^{64 / 67} \mathrm{Cu}$ from the Matrix of Neutron-Irradiated Natural Zinc Applicable for ${ }^{64} \mathrm{Cu}$ Production
}

\author{
S. Soenarjo , Sriyono, W.Y. Rahman, E. Sarmini, Hambali and Triyanto \\ Center for Radioisotopes and Radiopharmaceuticals, National Nuclear Energy Agency \\ Puspiptek, Serpong, Tangerang 15314, Indonesia
}

\section{ARTICLE INFO}

Article history:

Received 28 June 2011

Received in revised form 21 February 2012

Accepted 24 February 2012

Keywords:

Radioisotope ${ }^{64} \mathrm{Cu}$

Nuclear reaction of ${ }^{64} \mathrm{Zn}(\mathrm{n}, \mathrm{p}){ }^{64} \mathrm{Cu}$

Radionuclidic separation of ${ }^{64} \mathrm{Cu}$

Neutron irradiation of natural $\mathrm{Zn}$

Molecular-targeted-radiopharmaceutical

\begin{abstract}
A B S T R A C T
Radioisotope ${ }^{64} \mathrm{Cu}$ is a promising radiometallic-isotope for molecular-targetedradiopharmaceuticals. Having a half-life of 12.70 hours and emitting $\beta^{+}$-radiation $\left(\mathrm{E}_{\beta_{+}}=0.6531 \mathrm{MeV}\right)$ as well as $\beta^{-}$ray $\left(\mathrm{E}_{\beta-}=0.5787 \mathrm{MeV}\right)$, it is widely used in the form of biomedical-substrate-radiopharmaceutical for positron emission tomography (PET) diagnosis and simultaneously for targeted radiotherapy of cancer. The potential needs on the availability of ${ }^{64} \mathrm{Cu}$-labeled pharmaceuticals for domestic nuclear medicine hospitals lead to a necessity for the local production of carrier-free ${ }^{64} \mathrm{Cu}$ using BATAN's G.A. Siwabessy reactor because of the technical and economical constraints in the production using BATAN's cyclotron. The presented work is accordingly to study whether the radioisotope ${ }^{64} \mathrm{Cu}$ can be produced and separated from the matrix of post-neutron-irradiated-natural zinc. This study is expected can be further improved and implemented in production technology of carrier-free ${ }^{64} \mathrm{Cu}$ based on ${ }^{64} \mathrm{Zn}(\mathrm{n}, \mathrm{p}){ }^{64} \mathrm{Cu}$ nuclear reaction exploiting the fast neutron fraction among the major thermal fraction due to unavailability of fast-neutron-irradiation facility in the BATAN's G.A. Siwabessy reactor. The solution of post-neutron-irradiated-natural zinc in $1 \mathrm{M}$ acetic acid was loaded into Chelex-100 cation exchanger resin column to pass out the $\mathrm{Zn} / \mathrm{Zn}$ * fraction whereas the $\mathrm{Cu}^{*}$ fraction which remained in the column was then eluted out from the column by using $1.5 \mathrm{M} \mathrm{HCl}$ and loaded into the second column containing Dowex-1X8 anion exchanger resin. The second column was then eluted with $0.5 \mathrm{M}$ $\mathrm{HCl}$. The collected eluate was expected to be zinc-free $\mathrm{Cu}^{*}$ fraction. It was observed from the half-life and the $\gamma$-spectrometric analysis that radioactive copper- ${ }^{64} \mathrm{Cu}$ containing ${ }^{67} \mathrm{Cu}$ was produced by neutron activation on the natural $\mathrm{Zn}$ foil target and can be separated from the target matrix by the presented two-stepscolumn-chromatographic separation technique. The radioactivity measurement showed that wrapping the $\mathrm{Zn}$ target with cadmium foil increased the activity of radioactive copper and, thus, the $\mathrm{Cu} * / \mathrm{Zn} *$-ratio.
\end{abstract}

\section{INTRODUCTION}

Turning out attention to the development of molecular-targeted-radiopharmaceuticals, researches on production of metal radionuclides emitting both $\beta^{-}$(negatron) and $\beta^{+}$(positron) are incited to provide suitable radioisotope for diagnostic and therapeutic radiopharmaceuticals. Among the promising radiometalic-isotopes being reported is radiocopper $-{ }^{64} \mathrm{Cu}$ [1] which decays by various ways i.e. positron decay $(17.86 \%$, $\mathrm{E}_{\beta_{+}}=0.6531 \mathrm{MeV}$ ) followed by emission of $\gamma$-annihilation radiation $\left(\mathrm{E}_{\gamma}=0.511 \mathrm{MeV}\right)$, negatron

\footnotetext{
* Corresponding author.

E-mail address: soenarjo@batan.go.id
}

decay $\left(39.0 \%, \mathrm{E}_{\beta-}=0.5787 \mathrm{MeV}\right)$, electron capture $(43.075 \%)$ and internal conversion $(0.475 \%)$ [2,3] emitting a higher energy of $\gamma$-ray $\left(E_{\gamma}=1.34579\right.$ $\mathrm{MeV}$ ) that is often not appeared clearly on the presentation of its $\gamma$-ray spectra because the intensity is very low.

Having a half-life of 12.7 hours, the ${ }^{64} \mathrm{Cu}$ is suitable to label biomedical substrates with slow biological up-take kinetics such as peptide and antibody monoclonal compounds. As a $\beta^{+}$-emitter, ${ }^{64} \mathrm{Cu}$ is used in positron emission tomography (PET) diagnostics giving an easier radiation dose estimation when compared to the shorter halflife PET nuclides such as ${ }^{18} \mathrm{~F}\left(\mathrm{t}_{1 / 2}=110 \mathrm{~min}\right)$ and ${ }^{11} \mathrm{C}\left(\mathrm{t}_{1 / 2}=20 \mathrm{~min}\right)$ [4]. As a $\beta^{-}$-emitter, it can be simultaneously used for targeted 
radiotherapy of cancer [1]. Many researches leading to the application of various ${ }^{64} \mathrm{Cu}$-labeled radiopharmaceuticals for both medical diagnosis and therapy have been reported [5-9]. An extensive review on the chelation chemistry of copper and its role in copper radiopharmaceutical (specifically ${ }^{64} \mathrm{Cu}$-radiopharmaceuticals) has also been available [10]. In Indonesia, however, the application of ${ }^{64} \mathrm{Cu}$ radiopharmaceuticals can not be offered yet because of the lack of capability on the production technology of carrier-free ${ }^{64} \mathrm{Cu}$ [11].

This radioisotope can be produced from both nuclear reactor and cyclotron. In a research nuclear reactor such as BATAN's G.A. Siwabessy reactor in Serpong, the radiocopper- ${ }^{64} \mathrm{Cu}$ can be produced by means of simple $(\mathrm{n}, \gamma)$-nuclear reaction using highenriched ${ }^{63} \mathrm{Cu}$ target, but by this nuclear reaction type the radioactive product can not be separated from its stable isotope in the target matrix. Accordingly, the specific activity of the product will be relatively low and mostly unsatisfactory to be used for medical purposes. The (n,p)-based nuclear reaction using high-enriched ${ }^{64} \mathrm{Zn}$ target is an alternative way to produce ${ }^{64} \mathrm{Cu}$ from nuclear reactor giving carrier-free (high specific activity) product [12]. This nuclear reaction needs fast neutron beams but there is no irradiation facility using fast neutron fraction available in the G.A. Siwabessy reactor. The bombardment of thermal neutron on the ${ }^{64} \mathrm{Zn}$ target will mainly produce radioisotope ${ }^{65} \mathrm{Zn} \quad\left(\mathrm{t}_{1 / 2}=244\right.$ days, $\mathrm{E}_{\gamma}=1.115 \mathrm{MeV}$ ). If natural $\mathrm{Zn}$ is used as target, based on the composition of natural isotopic abundance of $\mathrm{Zn}[13,14]$, other radioactive $\mathrm{Zn}$ will also be produced $\left({ }^{69} \mathrm{Zn},{ }^{69 m} \mathrm{Zn},{ }^{71} \mathrm{Zn}\right.$ and $\left.{ }^{71 \mathrm{~m}} \mathrm{Zn}\right)$, but their half-lives are very short as compared to the ${ }^{65} \mathrm{Zn}$. The nuclear reaction based on proton activation in the BATAN's cyclotron in Serpong is accordingly important to be considered as a choice to produce carrier-free radioactive copper- $-{ }^{64} \mathrm{Cu}$, but it still has big constraints related to either technical or economical consideration. The nuclear reaction of ${ }^{68} \mathrm{Zn}(\mathrm{p}, \alpha \mathrm{n}){ }^{64} \mathrm{Cu}$ needs proton beam energy of more than $30 \mathrm{MeV}$ [15] which can not be achieved by the BATAN's cyclotron machine, so technically it can not be performed in BATAN. In other side, the nuclear reaction of ${ }^{64} \mathrm{Ni}(\mathrm{p}, \mathrm{n}){ }^{64} \mathrm{Cu} \quad[11,16-18]$ requiring less than $25 \mathrm{MeV}$ of proton beam energy can be technically performed but the high-enriched ${ }^{64} \mathrm{Ni}$ is very expensive (about $\$ 18 / \mathrm{mg}$ in 2007) [10], due to its very low natural abundance, which is only $0.9256 \%$ [19], so it is still difficult to be implemented by the reason of economy.

Because of the potential needs on the availability of ${ }^{64} \mathrm{Cu}$-labeled pharmaceuticals for domestic nuclear medicine hospitals, the local production of carrier-free ${ }^{64} \mathrm{Cu}$ using BATAN's G.A. Siwabessy reactor becomes a necessity. Among the neutron beams in the G.A. Siwabessy reactor, the existing fast neutron fraction might be probable to be exploited for irradiating the Zn-target while the thermal neutron fraction is prevented to bombard the target. This prevention is expected can be carried out by means of wrapping the target with cadmium foil or placing the target in a boronirradiation tube.

The presented work is aimed, therefore, to study whether the carrier-free ${ }^{64} \mathrm{Cu}$ can be produced in G.A. Siwabessy reactor and, if so, to gain technical procedure for the separation of the resulting ${ }^{64} \mathrm{Cu}$ from the matrix of neutron-irradiated Zn-target. By the economical consideration, the presented work is performed using natural $\mathrm{Zn}$-target instead of the high-enriched ${ }^{64} \mathrm{Zn}$, and cadmium foil wrap instead of boron-irradiation tube. The presented works were expected can be further improved and implemented in ${ }^{64} \mathrm{Cu}$ - production technology based on ${ }^{64} \mathrm{Zn} \quad(\mathrm{n}, \mathrm{p}){ }^{64} \mathrm{Cu}$ nuclear reaction.

\section{EXPERIMENTAL METHODS}

\section{Materials and equipments}

The natural Zn-target foil having purity of 99.9\% (from Sigma-Aldrich) was put ready in small pieces form. Quartz tubes of irradiation grade used as irradiation tubes, as well as inner and outer capsules for irradiation which were made of highpurity aluminium, were produced by local company. Foil of natural cadmium (Cd-foil) having purity of $99.99 \%$ (from Sigma-Aldrich) was used as wrapper for the quartz tube containing the Zn-target. Two types of ion exchanger resins, i.e. Chelex-100 $(100-200$ mesh) cation exchanger and Dowex-1X8 (200 - 400 mesh) anion exchanger (both from Bio-Rad Richmond) were used for chromatographic separation using glass column $(\varnothing \quad 10 \mathrm{~mm}$, h $200 \mathrm{~mm}$ ) made by local company. The chemical materials used as mobile phase in columnchromatographic separation or as solvent were pro analysis grade (from E. Merck) and diluted as necessary using demineralized water (aqua DM) from water purification facility in Multi Purposes Reactor Center, BATAN, Serpong.

The target-contained-quartz tubes were closed by acetylene-glass welder, whereas the inner irradiation capsules were closed by argonwelding machine Super Tic 180. The welding result was then leak-tested by means of bubble test using vacuum pump Varian DD-20. A well-type 
dose calibrator (Atom Lab) was used for radioactivity measurement. A $\gamma$-spectrometer system equipped with multi channels analyser (Canberra 1000) and HP-Ge detector of Canberra Industries was used for radionuclidic analysis. The system was calibrated using a set of standard-sealed-sources comprising ${ }^{133} \mathrm{Ba}(302.85$ and $356.01 \mathrm{keV}),{ }^{137} \mathrm{Cs}$ $(661.64 \mathrm{keV})$ and ${ }^{60} \mathrm{Co}(1,173.23$ and $1,332.51 \mathrm{keV})$ from Du Pont [11].

\section{Target preparation and post-irradiation treatment}

An approximately $500 \mathrm{mg}$ of natural $\mathrm{Zn}$-target pieces were placed in quartz tube which was then closed by acetylene-glass welding and then wrapped using cadmium foil. The wrapping target was then placed into inner irradiation capsule which was then closed by argon-welding. After passing the leak-bubble test, the inner irradiation capsule was put into the outer capsule and this set of target was then sent to G.A. Siwabessy reactor to be irradiated at the CIP (central irradiation position). An unwrapped target was treated similarly as comparator.

The post-irradiated target was transported into the receiving hot cell and kept for several hours before further processing in order to allow the decay of the short-lived radioisotope produced. The quartz tube was brought out from the irradiation capsule and the Cd-foil wrap, and broken at the tip to transfer its content into a $100 \mathrm{~mL}$ glass beaker. The irradiated $\mathrm{Zn}$ was then dissolved in concentrate $\mathrm{HCl}(5 \mathrm{~mL})$. The resulting solution was heated to dryness, and then the residue was re-dissolved with $1 \mathrm{M}$ acetic acid solution (4.5 - $5 \mathrm{~mL}$ ). The resulting solution was labelled as Bulk Solution.

\section{Column preparation and radionuclidic separation}

Two glass columns containing Chelex-100 cation resin and Dowex-1X8 anion resin respectively were prepared. Each column was filled with about $6 \mathrm{ml}$ of resin-bed volume (7.5 cm of height) and conditioned with $1 \mathrm{M}$ acetic acid $(\mathrm{pH}=\sim 2.7)$ for the cation exchanger column and with $1 \mathrm{M} \mathrm{HCl}$ for the anion exchanger column. The radionuclidic separation procedure was a two-steps-chromatographic column technique adopted from the method reported by Zinn, et al. [12]. A volume of $3 \mathrm{~mL}$ of Bulk Solution was cited and loaded into the Chelex-100 column and passed out the column into a Bottle-A. The column was washed with $15 \mathrm{~mL}$ of $1 \mathrm{M}$ acetic acid solution and then with $3 \mathrm{~mL}$ of water. All the eluate-washings were assumed as $\mathrm{Zn} / \mathrm{Zn}^{*}$-fraction (the asterisk “*” indicates radioactive species) and collected in Bottle-A. The Chelex-100 cation exchanger column was then eluted with $10 \mathrm{~mL}$ of $1.5 \mathrm{M} \mathrm{HCl}$ solution to pass off the raw- $\mathrm{Cu}^{*}$-fraction from the column which was separately collected into a Bottle-B.

The content of the Bottle-B was loaded into the Dowex-1X8 anion exchanger column and passed out the column into a Bottle-C followed with washing the Dowex-1X8 column using 10 $\mathrm{mL}$ of $0.5 \mathrm{M} \mathrm{HCl}$. The eluate was collected and combined in the Bottle-C and assumed as pure$\mathrm{Cu}^{*}$-fraction. The whole column chromatographic separation is shown in Fig. 1.

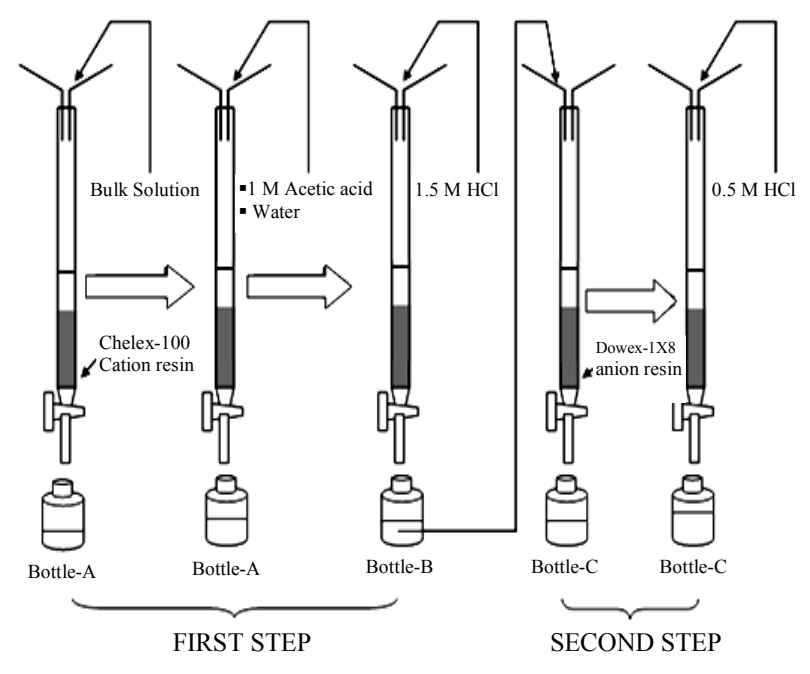

Fig. 1. Separation procedure using two steps of chromatographic column.

\section{Radioactivity analysis}

The radioactivity analysis comprised direct measurement of radioactivity, $\gamma$-ray spectrometry and half-life determination. The measurement of radioactivity was carried out directly using a well-type dose calibrator. For the $\gamma$-ray spectrometry, a $5-20 \mu \mathrm{L}$ of sample was pipetted out, spotted and adsorbed on a 2-cm-diameter filter paper. The filter paper was dried and put into a small plastic bag and then counted by using calibrated $\gamma$-spectrometer to gain the $\gamma$-ray spectra. The half-life of the $\mathrm{Cu}^{*}$ sample was determined by repeated measurement of its radioactivity and 
plotting the results as a function of decay time. The resulting decay curve was compared to theoretical calculation using a half-life value of 12.70 hours [13].

\section{RESULTS AND DISCUSSION}

Naturally occurring zinc $(\mathrm{Zn})$ is composed of five stable isotopes: ${ }^{64} \mathrm{Zn},{ }^{66} \mathrm{Zn},{ }^{67} \mathrm{Zn},{ }^{68} \mathrm{Zn}$ and ${ }^{70} \mathrm{Zn}$ with ${ }^{64} \mathrm{Zn}$ being the most abundant [18]. Their natural abundance, $(n, \gamma)$ and $(n, p)$-nuclear reactions and products are shown in Table 1 .

Table 1. Natural abundance of $\mathrm{Zn}$-isotopes and their $(\mathrm{n}, \gamma)$ and $(\mathrm{n}, \mathrm{p})$-nuclear reactions.

\begin{tabular}{|c|c|c|c|c|c|}
\hline \multirow{3}{*}{$\begin{array}{c}\text { ISOTOPE } \\
\text { AND } \\
\text { ABUNDANCE }\end{array}$} & \multicolumn{5}{|c|}{ NUCLEAR REACTIONS AND PRODUCTS $[(n, \gamma)$ and $(n, p)]$} \\
\hline & \multirow{2}{*}{$\begin{array}{l}\text { Nuclear } \\
\text { reaction }\end{array}$} & \multirow{2}{*}{$\begin{array}{c}\text { Cross } \\
\text { section } \\
\left(\times 10^{-3} \text { barn }\right)\end{array}$} & \multirow{2}{*}{$\begin{array}{c}t_{1 / 2} \text { of } \\
\text { product }^{[13]}\end{array}$} & \multicolumn{2}{|c|}{ Important $\gamma$-rays } \\
\hline & & & & $\mathbf{E}_{\mathbf{7}}(\mathrm{MeV})$ & Intensity (\%) ${ }^{[13]}$ \\
\hline \multirow{2}{*}{$\begin{array}{c}{ }^{64} \mathrm{Zn} \\
(48.63 \%)^{[13,14]}\end{array}$} & ${ }^{64} \mathrm{Zn}(\mathrm{n}, \gamma){ }^{65} \mathrm{Zn}$ & $\begin{array}{l}790^{[14]} \\
787^{[20]}\end{array}$ & $244.26 \mathrm{~d}$ & $\begin{array}{c}1.1155 \\
0.511\end{array}$ & $\begin{array}{l}50.60 \\
3 \text { (annihilation) }{ }^{[24]}\end{array}$ \\
\hline & ${ }^{64} \mathrm{Zn}(\mathrm{n}, \mathrm{p}){ }^{64} \mathrm{Cu}$ & $37.4^{[21]}$ & $12.70 \mathrm{~h}$ & $\begin{array}{l}0.511 \\
1.346\end{array}$ & $\begin{array}{l}36 \text { (annihilation) }^{[25]} \\
0.473\end{array}$ \\
\hline \multirow{2}{*}{$\begin{array}{c}{ }^{66} \mathrm{Zn} \\
(27.90 \%)^{[13,14]}\end{array}$} & ${ }^{66} \mathrm{Zn}(\mathrm{n}, \gamma){ }^{67} \mathrm{Zn}$ & $\begin{array}{l}620^{[14]} \\
618^{[20]}\end{array}$ & stable & - & - \\
\hline & ${ }^{66} \mathrm{Zn}(\mathrm{n}, \mathrm{p}){ }^{66} \mathrm{Cu}$ & $0.775^{[22]}$ & $5.12 \mathrm{~min}$ & 1.039 & 9 \\
\hline \multirow{2}{*}{$\begin{array}{c}{ }^{67} \mathrm{Zn} \\
(4.10 \%)^{[13,14]}\end{array}$} & ${ }^{67} \mathrm{Zn}(\mathrm{n}, \gamma){ }^{68} \mathrm{Zn}$ & $\begin{array}{l}7500^{[14]} \\
7472^{[20]}\end{array}$ & stable & - & - \\
\hline & ${ }^{67} \mathrm{Zn}(\mathrm{n}, \mathrm{p}){ }^{67} \mathrm{Cu}$ & $1.37^{[21]}$ & $61.83 \mathrm{~h}$ & 0.1846 & 48.7 \\
\hline \multirow{4}{*}{$\begin{array}{c}{ }^{68} \mathrm{Zn} \\
(18.75 \%)^{[13,14]}\end{array}$} & ${ }^{68} \mathrm{Zn}(\mathrm{n}, \gamma){ }^{69} \mathrm{Zn}$ & $\begin{array}{l}1000^{[14]} \\
1066^{[20]}\end{array}$ & $56.4 \mathrm{~min}$ & 318.71 & 0.0012 \\
\hline & ${ }^{68} \mathrm{Zn}(\mathrm{n}, \gamma){ }^{69 m} \mathrm{Zn}$ & $72^{[14]}$ & $13.76 \mathrm{~h}$ & 0.4386 & 94.77 \\
\hline & ${ }^{68} \mathrm{Zn}(\mathrm{n}, \mathrm{p}){ }^{68} \mathrm{Cu}$ & $0.0154^{[23]}$ & $31.10 \mathrm{~s}$ & 1.077 & 64 \\
\hline & ${ }^{68} \mathrm{Zn}(\mathrm{n}, \mathrm{p}){ }^{68 \mathrm{~m}} \mathrm{Cu}$ & $0.00369^{[23]}$ & $3.8 \mathrm{~min}$ & 1.077 & 12 \\
\hline \multirow{3}{*}{$\begin{array}{c}{ }^{70} \mathrm{Zn} \\
(0.62 \%)^{[13,14]}\end{array}$} & ${ }^{70} \mathrm{Zn}(\mathrm{n}, \gamma)^{7 \mathrm{l}} \mathrm{Zn}$ & $\begin{array}{l}83^{[14]} \\
92^{[20]}\end{array}$ & $2.45 \mathrm{~min}$ & 0.5116 & $\begin{array}{l}32 \\
\text { (no annihilation) }\end{array}$ \\
\hline & ${ }^{70} \mathrm{Zn}(\mathrm{n}, \gamma)^{7 \mathrm{~lm}} \mathrm{Zn}$ & $8.7^{[14]}$ & $3.96 \mathrm{~h}$ & 0.3863 & 93 \\
\hline & ${ }^{70} \mathrm{Zn}(\mathrm{n}, \mathrm{p}){ }^{70} \mathrm{Cu}$ & No data & $4.5 \mathrm{~s}$ & 0.8849 & 54 \\
\hline
\end{tabular}

It is shown from Table 1 that the $(\mathrm{n}, \gamma)$ nuclear reaction on ${ }^{\mathrm{NAT}} \mathrm{Zn}$ will produce 5 radioactive zinc species whereas the $(\mathrm{n}, \mathrm{p})$ nuclear reaction will produce 6 radioactive copper species. The $(n, \alpha)$-nuclear reaction will also happen producing radioactive nickel but the cross section is very small [21], so it is left out of consideration. Among the radioactive zinc and copper being mentioned in Table $1,{ }^{65} \mathrm{Zn},{ }^{69} \mathrm{Zn}$, ${ }^{69 \mathrm{~m}} \mathrm{Zn},{ }^{71 \mathrm{~m}} \mathrm{Zn},{ }^{64} \mathrm{Cu}$ and ${ }^{67} \mathrm{Cu}$ are important to be taken into consideration, whereas the others are less important because they have short half-lives and, so, almost none will be left by the end of the running experiments. Nevertheless, it can be seen in Fig. 2, the dissolved post-neutron-irradiatednatural zinc (the Bulk Solution) shows peaks energy of $\gamma$-rays at $438 \mathrm{keV}\left({ }^{69 \mathrm{~m}} \mathrm{Zn}\right), 511 \mathrm{keV}$ (annihilation of ${ }^{65} \mathrm{Zn}$ and ${ }^{64} \mathrm{Cu}$ ) and $1,115 \mathrm{keV}$ $\left({ }^{65} \mathrm{Zn}\right)$. The peaks energy of other $\gamma$-rays from ${ }^{69} \mathrm{Zn},{ }^{71 \mathrm{~m}} \mathrm{Zn},{ }^{64} \mathrm{Cu}$ and ${ }^{67} \mathrm{Cu}$ are not visible because their net areas are too small as compared to the existing main peaks due to either the intensity of the $\gamma$-ray or the cross section of the corresponding nuclear reaction is too low.

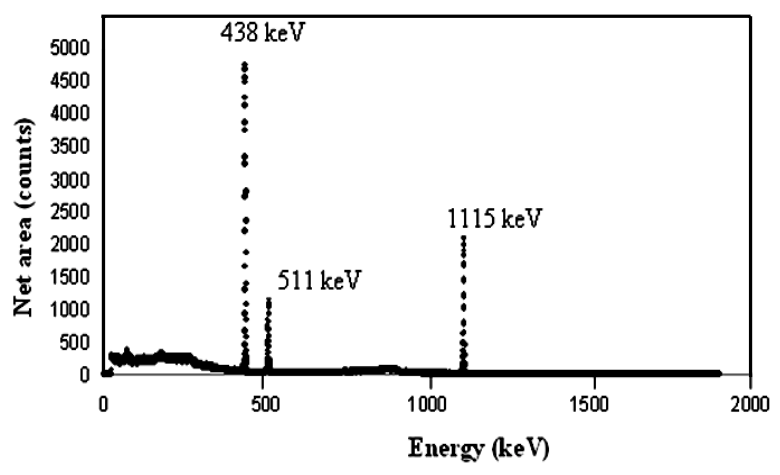

Fig. 2. Typical $\gamma$-spectrum of the dissolved post-neutronirradiated-natural zinc (Bulk Solution).

The radionuclidic separation of the matrix in the dissolved post-irradiated target was then performed by means of two-steps chromatographic column using cation and anion exchanger resins successively [12]. The resulting fractions were collected in three receivers labeled as Bottle-A, Bottle-B and Bottle-C respectively as can be seen from Fig. 1 and Table 2.

Table 2. Radionuclidic separation system

\begin{tabular}{|c|c|c|c|}
\hline \multicolumn{2}{|c|}{ FIRST COLUMN } & \multicolumn{2}{|c|}{ SECOND COLUMN } \\
\hline \multicolumn{2}{|c|}{$\begin{array}{l}\text { Type of resin : Chelex- } 100 \\
\text { cation exchanger } \\
\text { Sample to be loaded : Bulk } \\
\text { Solution }\end{array}$} & \multicolumn{2}{|c|}{$\begin{array}{l}\text { Type of resin : Dowex-1X8 } \\
\text { anion exchanger } \\
\text { Sample to be loaded : Fraction } \\
\text { in Bottle-B }\end{array}$} \\
\hline Eluent & $\begin{array}{l}\text { Resulting } \\
\text { fraction }\end{array}$ & Eluent & $\begin{array}{l}\text { Resulting } \\
\text { fraction }\end{array}$ \\
\hline $1 \mathrm{M}$ acetic acid & Bottle-A & None & Bottle-C \\
\hline Water & $\begin{array}{l}\text { Bottle-A } \\
\text { (combined) }\end{array}$ & & \\
\hline $1.5 \mathrm{M} \mathrm{HCl}$ & $\begin{array}{l}\text { Bottle-B } \\
\text { (loaded into } \\
\text { the second } \\
\text { column) }\end{array}$ & $0.5 \mathrm{M} \mathrm{HCl}$ & $\begin{array}{l}\text { Bottle-C } \\
\text { (combined) }\end{array}$ \\
\hline
\end{tabular}

The $\gamma$-spectrometry analysis for the resulting fraction samples were then performed as similar to that for the Bulk Solution. The results were presented in Fig. 3, showing a typical $\gamma$-spectrum of the resulting fraction collected in Bottle-A, Bottle-B and Bottle-C successively.

Comparing to Fig. 2, it can be presumed that the Bottle-A (represented by Fig. 3(a)) contained $\mathrm{Zn} / \mathrm{Zn}$ * fraction showing peaks position precisely similar to the Bulk Solution. It indicated that in the condition of weak acid ( $1 \mathrm{M}$ acetic acid), the 
$\mathrm{Zn} / \mathrm{Zn}$ * fraction was mostly unbound by the cation exchanger resin. The intensity of the peak $511 \mathrm{keV}$, however, became to be lower indicating that the $\gamma$-annihilation of ${ }^{64} \mathrm{Cu}$ gave no more contribution as the ${ }^{64} \mathrm{Cu} / \mathrm{Cu}^{*}$ was retained in the column in the form of ${ }^{64} \mathrm{Cu} / \mathrm{Cu}^{*{ }^{2+}}$ cation. The peak $511 \mathrm{keV}$, thus, was expected coming from annihilation of ${ }^{65} \mathrm{Zn}$ [24].
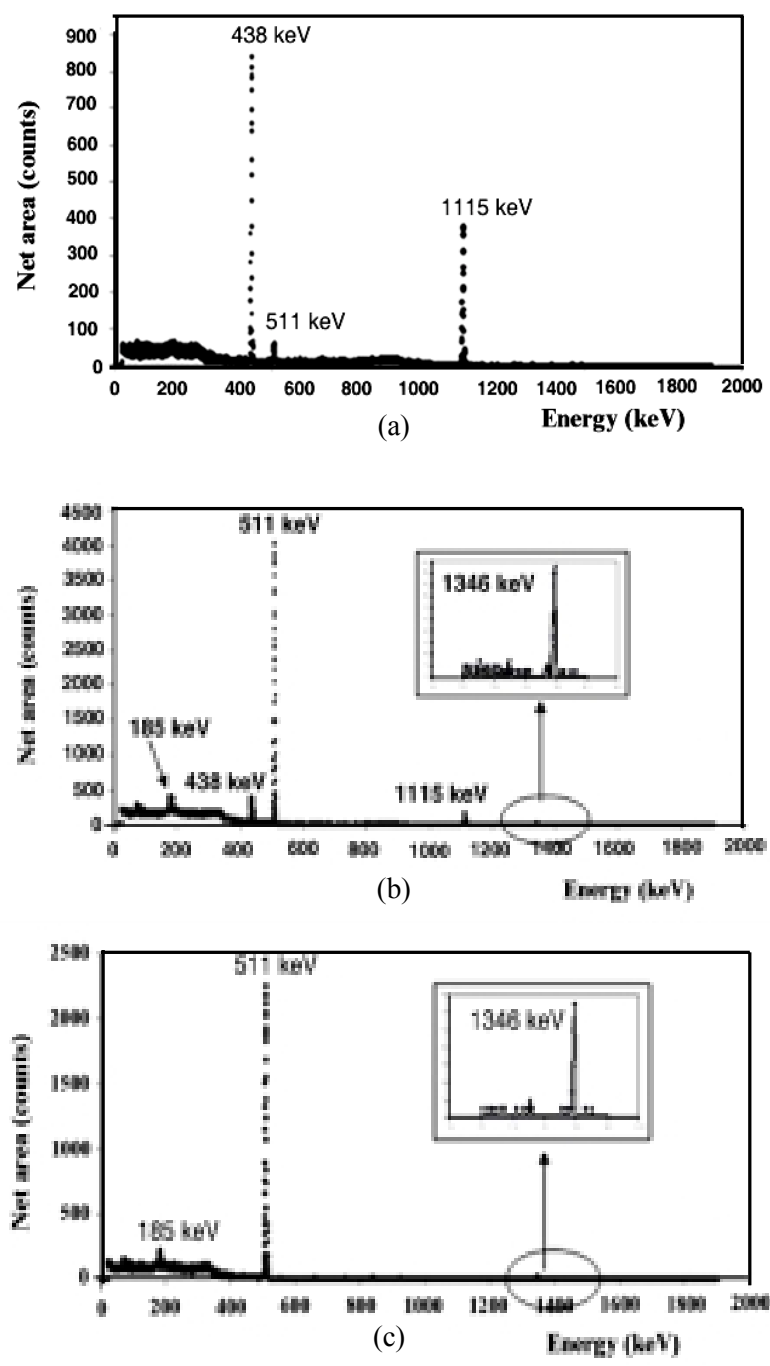

Fig. 3. Typical $\gamma$-spectrum of the separating fraction collected in Bottle-A (a), Bottle-B (b) and Bottle-C (c).

Comparing to Fig. 2, it can be presumed that the Bottle-A (represented by Fig. 3(a)) contained $\mathrm{Zn} / \mathrm{Zn}$ * fraction showing peaks position precisely similar to the Bulk Solution. It indicated that in the condition of weak acid (1 $\mathrm{M}$ acetic acid), the $\mathrm{Zn} / \mathrm{Zn}$ * fraction was mostly unbound by the cation exchanger resin. The intensity of the peak $511 \mathrm{keV}$, however, became to be lower indicating that the $\gamma$-annihilation of ${ }^{64} \mathrm{Cu}$ gave no more contribution as the ${ }^{64} \mathrm{Cu} / \mathrm{Cu}^{*}$ was retained in the column in the form of ${ }^{64} \mathrm{Cu} / \mathrm{Cu}^{* 2+}$ cation. The peak $511 \mathrm{keV}$, thus, was expected coming from annihilation of ${ }^{65} \mathrm{Zn}$ [24].
Eluting the first chromatographic column using $1.5 \mathrm{M} \mathrm{HCl}$ released the retained $\mathrm{Cu}^{*}$ fraction out of the column that was collected in the Bottle-B. This fraction showed a strong peak at $511 \mathrm{keV}$ in accordance with the $\gamma$-annihilation of ${ }^{64} \mathrm{Cu}$ (Fig. 3(b)). The two strong peaks of $\mathrm{Zn}^{*}$, i.e. 438 $\mathrm{keV}\left({ }^{69 \mathrm{~m}} \mathrm{Zn}\right)$, and $1115 \mathrm{keV}\left({ }^{65} \mathrm{Zn}\right)$, were still appeared but with much lower intensities, indicating that a small part of $\mathrm{Zn} / \mathrm{Zn}$ * was still in. A new peak was appeared at $185 \mathrm{keV}$ in agree with the $\gamma$-ray emitted by ${ }^{67} \mathrm{Cu}$, and a very small peak at $1346 \mathrm{keV}$, which can only be observed by partial magnification, was in agree with the $\gamma$-ray of ${ }^{64} \mathrm{Cu}$ [11]. The data explained that in the condition of $1.5 \mathrm{M} \mathrm{HCl}$, the $\mathrm{Cu}^{*}$ fraction was changed to anion complex $\mathrm{Cu}^{*} \mathrm{Cl}_{4}{ }^{2-}$ and passed out the column.

The $\mathrm{Cu}^{*}$-fraction, which contained a small part of $\mathrm{Zn}^{*}$, was then loaded into the second column containing anion exchanger resin, followed by elution with $0.5 \mathrm{M} \mathrm{HCl}$. The resulting eluate showed no more peaks of $\mathrm{Zn}$ * but a strong peak at $511 \mathrm{keV}$ in agree with the $\gamma$-annihilation of ${ }^{64} \mathrm{Cu}$ and a weaker one at $185 \mathrm{keV}$ in agree with the $\gamma$-ray of ${ }^{67} \mathrm{Cu}$ (Fig. 3(c)). A very small peak at $1,346 \mathrm{keV}$ was also observed by partial magnification agreeing with the $\gamma$-ray of ${ }^{64} \mathrm{Cu}$. The data indicate that in the condition of $0.5 \mathrm{M} \mathrm{HCl}$ the $\mathrm{Zn} / \mathrm{Zn}^{*}$ fraction was in the form of $\mathrm{Zn}^{*} \mathrm{Cl}_{4}{ }^{2-}$ anion complex and retained in the anion exchanger column while the $\mathrm{Cu}^{*}$ fraction was in the form of $\mathrm{Cu}^{* 2+}$ and passed out from the column. The observed data seemed to agree with the published data presented by Jentzsch and Frotsher showing anionic complexes of some elements in presence of various concentration of $\mathrm{HCl}$ [26] and met the report of Csicsovszki, et al, stating that zinc is to form negatively charged chloro-complex species even if the $\mathrm{HCl}$ concentration is relatively low [27].

The measurement of half-life is other important thing accompanying radiation spectrometry in order to determine a radionuclide. The $\mathrm{Cu}^{*}$ fraction was accordingly subjected to this measurement by repeating the measurement of its activity. The decay curve was then prepared according to Equation-1 below :

$$
\ln \mathrm{A}(\mathrm{t})=\ln \mathrm{A}(0)-\lambda . \mathrm{t}
$$

where $\mathrm{A}=$ radioactivity, $\lambda=$ decay constant and $\mathrm{t}=$ decay time.

The resulting decay curve is presented in Fig. 4 as compared to theoretical line calculated using an internally-improved program [28] assuming that the half-life of ${ }^{64} \mathrm{Cu}$ was 12.7 hours. It can be seen that the decay curve of the resulting 
$\mathrm{Cu}^{*}$ fraction (curve-b) gave a linear relationship of $\ln A(t)$ vs. $t$. The slope and linearity coefficient value of this line were close by those of theoretical decay line (curve-a).

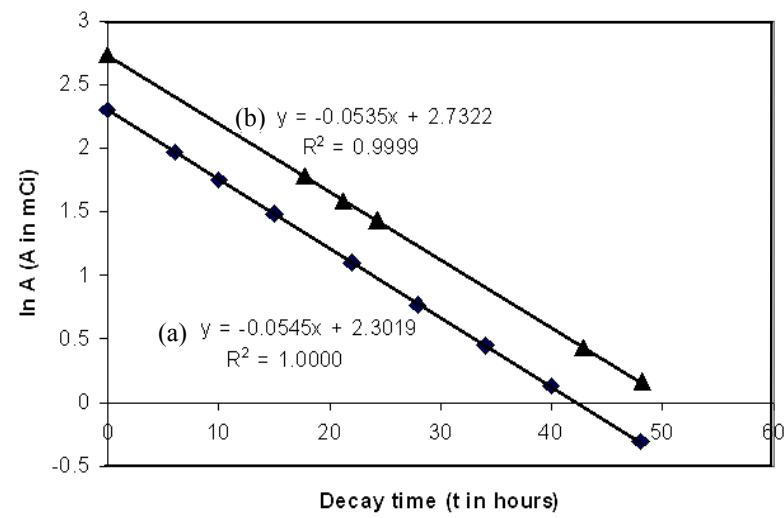

(a) Theoretical decay curve

(b) Experimental decay curve

Fig. 4. Typical decay curve of $\mathrm{Cu}^{*}$ fraction (b) as compared to theoretical curve assuming a half-life of $12.7 \mathrm{~h}$ (a).

Further calculation, however, gave a half-life value of $12.95 \mathrm{~h}$, slightly higher than the assumed value $(12.70 \mathrm{~h})$, perhaps because the $\mathrm{Cu}^{*}$ fraction contained also ${ }^{67} \mathrm{Cu}$ having a half-life of $61.83 \mathrm{~h}$. The conformity of the obtained $\gamma$-ray energy and the half-life showed that the radioactive ${ }^{64} \mathrm{Cu}$ can be produced by neutron irradiation on natural $\mathrm{Zn}$, as well as on high-enriched ${ }^{64} \mathrm{Zn}$, in the BATAN's G.A. Siwabessy reactor and can be separated from the post-irradiated target by means of the presented chromatographic column method. The use of highenriched ${ }^{64} \mathrm{Zn}$ target should be preferred, in term of product quality, because by using natural $\mathrm{Zn}$-target the end product of ${ }^{64} \mathrm{Cu}$ was still contaminated by ${ }^{67} \mathrm{Cu}$, even though the possibility of ${ }^{67} \mathrm{Cu}$ formation is too low if compared to that of ${ }^{64} \mathrm{Cu}$.

Table 3. The effect of cadmium-foil wrap on the $\mathrm{Cu} * / \mathrm{Zn}^{*}$-ratio.

\begin{tabular}{|c|c|c|c|c|}
\hline No & VARIABLES COMPARED & PROCESS-1 & PROCESS-2 & PROCESS - 3 \\
\hline 1 & Weight of $\mathrm{Zn}$ target & $0.533 \mathrm{~g}$ & $0.500 \mathrm{~g}$ & $0.504 \mathrm{~g}$ \\
\hline 2 & Use of Cd-foil wrap & Yes & Yes & No \\
\hline 3 & Irradiation time & 96 hours & 60.5 hours & 86 hours \\
\hline 4 & $\begin{array}{l}\text { Total volume of post-irradiated target } \\
\text { solution(Bulk Solution) }\end{array}$ & $4.5 \mathrm{~mL}$ & $4.5 \mathrm{~mL}$ & $5 \mathrm{~mL}$ \\
\hline 5 & $\begin{array}{l}\text { Volumeof the Bulk solution treated } \\
\text { for separation }\end{array}$ & $3 \mathrm{~mL}$ & $3 \mathrm{~mL}$ & $3 \mathrm{~mL}$ \\
\hline 6 & Estimated radioactivity of $\mathrm{Zn}^{*}$ at $\mathrm{EOI}^{1}$ ) & $99.45 \mathrm{mCi}$ & $58.92 \mathrm{mCi}$ & $84.30 \mathrm{mCi}$ \\
\hline 7 & Radioactivity of $\mathrm{Cu}^{*}$ at $\mathrm{EOI}^{2}$ & $147.50 \mathrm{mCi}$ & $55.83 \mathrm{mCi}$ & $42.37 \mathrm{mCi}$ \\
\hline 8 & $\left(\mathrm{Cu}^{*} / \mathrm{Zn}^{*}\right)$-ratio at EOI $[(7)(6)]$ & 1.58 & 0.95 & 0.51 \\
\hline
\end{tabular}

REMARKS :

1). Calculated activity of the growing ${ }^{65} \mathrm{Zn}$ at the End of Irradiation (EOI) based on general formulation of : $\mathrm{A}=\phi . \sigma . \mathrm{N} .\left(1-\mathrm{e}^{-\lambda . t \text { tir }}\right)$. using the data written in the irradiation form without considering the effect of the Cd-foil wrap.

2). Assuming as ${ }^{64} \mathrm{Cu}$ based on radioactivity measurement at the end of the separation process.
The application of cadmium-foil to wrap the $\mathrm{Zn}$-target during the irradiation gave no significant effect to the separation or analytical procedures, but influenced the activity growth of the $\mathrm{Cu}^{*}$ and, thus, the $\mathrm{Cu}^{*} / \mathrm{Zn}^{*}$-ratio as presented in Table 3. It can be seen from Table 3 the growth of the $\mathrm{Cu}^{*}$ is larger in the Process-1 and the Process-2 (both were using Cd-foil wrap) as compared to the Process-3 (without Cd-foil wrap). In cases of Process-1 and Process-2, the thermal neutron beams were mostly absorbed by the Cd-foil as the Cd-element has a very high absorption for thermal neutron ( $\sigma=2,450$ barn) [29].

Accordingly, the ${ }^{\mathrm{NAT}} \mathrm{Zn}(\mathrm{n}, \mathrm{p}) \mathrm{Cu}^{*}$ nuclear reaction performed by the unabsorbed fast neutron fraction was to be more dominant as compared to the case of Process-3, in which the ${ }^{\mathrm{NAT}} \mathrm{Zn}(\mathrm{n}, \gamma) \mathrm{Zn}$ * nuclear reaction was to be more dominant. Consequently the activities of the $\mathrm{Cu}^{*}$ and, thus, the $\mathrm{Cu}^{*} / \mathrm{Zn}^{*}$-ratios obtained from the two-former processes were higher than that from the third process. However, the radioactivity yields of both $\mathrm{Zn}^{*}$ and $\mathrm{Cu}^{*}$ might fluctuate significantly. It was suspected to be inflicted by irradiation parameters applied which, in general, varied from one irradiation cycle to another and, moreover, the parameters fluctuated during a cycle of irradiation. Such parameters included the change of reactor power and the deviation of the neutron flux from time to time. In the other side, the average value of neutron flux on a certain irradiation position is significantly influenced by the target burden at the other position that may be different from one process to another process [30].

\section{CONCLUSION}

Radioisotopes ${ }^{64} \mathrm{Cu}$ and ${ }^{67} \mathrm{Cu}$ were simultaneously produced by neutron irradiation on natural $\mathrm{Zn}$ target together with radioactive zinc. The radioactive copper could be separated successively, from the post-irradiated target matrix by two steps of ion exchange chromatography using cation and anion exchanger resins.

The presented procedures were applicable to provide carrier-free ${ }^{64} \mathrm{Cu}$ based on ${ }^{64} \mathrm{Zn}$ $(\mathrm{n}, \mathrm{p}){ }^{64} \mathrm{Cu}$ as primary radioisotope used for diagnostic and therapeutic-molecular-targetedradiopharmaceutical. The used of high-enriched ${ }^{64} \mathrm{Zn}$ target is preferred, in term of product quality, rather than the natural $\mathrm{Zn}$.

Wrapping the $\mathrm{Zn}$ target by cadmium foil was able to diminish $(\mathrm{n}, \gamma)$-nuclear reaction on the target 
producing radioactive zinc and, in contrary, to increase the $(\mathrm{n}, \mathrm{p})$-nuclear reaction producing radioactive copper. Nevertheless, the radioactivity yields might fluctuate due to the change on irradiation and reactor operation parameters.

\section{REFERENCES}

1. M. Eiblmaier, Copper-64 Radiopharmaceuticals for Receptor-Mediated Tumor Imaging and Radiotherapy, Dissertation, Universitat Dresden (2008).

2. http://en.wikipedia.org/wiki/Copper-64. Retrieved in January (2010).

3. M.M. Be, V. Chiste and C. Dulieu, et al, Table of Radionuclides, vol. 1, Monographie BPIM-5, Bureau International des Poids et Mesures, Sevres (2004).

4. S. Watanabe, Y. Iida and N. Suzui, et al, J. of Radioanal. Nucl. Chem. 280 (2009) 199.

5. M.A. Green, Nucl. Med. Biol. 34 (2007) 247.

6. J.E. Sprague, J. Med. Chem. 50 (2007) 2527.

7. X. Sun, J. Biol. Inorg. Chem. 8 (2003) 217.

8. M.R. Lewis, M. Wang and D.B. Axworthy, et al, J. Nucl. Med. 44 (2003) 1284.

9. J.S. Lewis, Copper-64-diacetyl-bis(N4methyl-thio-semicarbazone) : An agent for radiotherapy, Proceedings of the National Academic of Science (2000) 1206.

10. T.J. Wadas, E.H. Wong and G.R. Weisman, et al, Curr. Pharm. Des. 13 (2007) 3.

11. S. Soenarjo, W.Y. Rahman and Sriyono, et al, Studies on Target Preparation and Radionuclidic Separation for Radioactive Copper Production based on ${ }^{64} \mathrm{Ni}(p, n){ }^{64} \mathrm{Cu}$ Reaction, Proceedings National Seminar on SATEK III (2010) 573 (in Indonesian).

12. K.R. Zinn and T.R. Chaudhuri, Cancer $\mathbf{7 3}$ (1994) 774.

13. S.Y.F. Chu, L.P. Ekström and R.B. Firestone, The Lund/LBNL Nuclear Data Search, version 2. http://nucleardata.nuclear.lu.se/nucleardata/toi (1999) Retrieved in April (2011).

14. http://www.kayelaby.npl.co.uk/atomic_and nuclear_physics/4_6/4_6_1_part03_030_039. html\#Zn. Retrieved in April (2011).
15. M.L. Bonardi, C. Birattari and F. Groppi, et al, Copper-64 Production Studies with Natural Zinc Targets at Deuteron Energy up to $19 \mathrm{MeV}$ and Proton Energy from 141 down to $31 \mathrm{MeV}$, Proceedings of the $8^{\text {th }}$ Conference on Astroparticle, Particle and Space Physics, Detectors and Medical Physics Applications (2003) 343.

16. W.D. McCarthy, R.E. Shefer and R.E. Klinkowstein, et al, Nucl. Med. Biol. 24 (1997) 35.

17. J.Y. Kim, H. Park and J.C. Lee, et al, Appl. Rad. Isot. 67 (2009) 1190.

18. P. Burke, O. Golovko and J.C. Clark, et al, Inorg. Chim. Acta 363 (2010) 1316.

19. http://en.wikipedia.org/wiki/Nickel-64. Retrieved in April (2010).

20. N. Iwamoto, J. Nucl. Sci. Tech. 44 (2007) 1131.

21. I.A. Abbasi, Nuclear Reaction Cross-Section Measurement and Model Calculations for Some Medically Important Radioisotopes, Thesis, Quaid-i-Azam University (2005).

22. I.M. Cohen, S.R. Guevara and M.A. Arribére, et al, Radiochim. Acta 93 (2005) 543.

23. A.J. Kestelman, G.S. Ribeiro and M.A. Arribére, et al, Appl. Rad. Isot. 65 (2007) 872.

24. http://hpschapters.org/northcarolina/NSDS/65Z nPDF.pdf. Retrieved in April (2011).

25. http://hpschapters.org/northcarolina/NSDS/64C uPDF.pdf. Retrieved in April (2011).

26. http://www.dow.com/PublishedLiterature/dh_00 5b/0901b8038005b46b.pdf?. Retrieved in April (2010).

27. G. Csicsovszki, T. Kekesi and T.I. Torok, Hydrometallurgy 77 (2005) 19.

28. Maskur and C.T. Rustandi, Information System for Radioisotopes Table Using Turbo Pascal Language on Windows, Proceedings of Computation on Nuclear Science and Technology (2008) 393 (in Indonesian).

29. http://environmentalchemistry.com/yogi/perio dic/crosssection.htm. Retrieved in May (2010).

30. T.M. Sembiring, A. Tarigan and M.D. Isnaini, Maximization of Radioisotopes Irradiation Target at RSG-GAS Research Reactor, Internal Document No. KK.04.04.65.08, Rev. 0, PRSG, BATAN (2008) (in Indonesian). 